\title{
EXAMINING THE EFFECT OF SHAPE, SIZE AND DISTANCE OF POPS IN THE NON-LINEAR BEHAVIOR OF STEEL SHEAR WALLS
}

\author{
Amin Adib Rahim Abadi \\ Department Of Civil Engineering, Qeshm Branch, Islamic Azad University, Qeshm, Iran \\ Yousef Zandi \\ Member Of Academic Staff, Department Of Civil Engineering, Tabriz Branch, Islamic Azad University \\ Tabriz, Iran
}

\begin{abstract}
The shape and place of the holes of shear walls are effective on tensions and the elastic and non-elastic transformation and also the formability, bending resistance and capacity of absorbing energy at times of earthquakes. Thus, it is necessary to pay attention to the non-linear behavior of steel shear walls with pops and consider some strategies for reinforcing the sides of the pops. The goal of this project is studying and deeper understanding of the strength and weakness points of pops, the effect of shape and place of pops on the functioning and behavior of shear walls in the non-linear area of steel shear walls. For this purpose, we present the results of a numeric study on steel shear walls with pops. The analyses are done by the limited components Abaqus program and are calibrated by experimental results. An area of subjects that is studied in the steel shear walls with pops includes final load, and load-displacement curves. The numeric results for steel shear walls with pops would also be compared. Finally, the calculated numeric results will be compared with the experimental results. Final load and load-displacement curves gained by the numeric analysis show a good adaptation with the results gained from related experiments. Results of numeric analysis in most cases indicate that this method is a conservative one. Thus, we could use this method in designing applications.
\end{abstract}

Keywords: steel shear walls, non-linear behavior, pops, Abaqus software

\section{INTRODUCTION}

Steel shear walls have been used since the 70s in various buildings particularly high buildings as a system with appropriate functioning, against the lateral forces. Steel shear wall consists of a refilling steel layer that is surrounded by a system of bars and pillars. This system is like a vertical steel foil bar that is placed in a cantilever way in which the pillars play the role of the wings of foil bar, while bars act as hardeners. High elastic hardness, great formability and hysterias sustainable behavior in coming and going loading are the features of this system. Buildings besides usual loads can undergo limited loads as well. Studying the behavior of buildings against loads like earthquakes, loads caused by clashing of objects and loads resulted from nearby or inside explosions has always been of great significance. Regarding the fact that our country is located in a seismic location and there is the possibility that in the designing of many previous constructs, the earthquake force has not been taken into account, thus, many of these constructs require reinforcement and invigoration against the earthquake force. Reinforcement of constructs for confronting the forces and fluctuations due to earthquake with new and various ways is among the relatively new domains in scientific areas. Steel shear walls are considered an effective construct for providing resistance for high and middle buildings against the lateral forces. The existence of pops in the elements of reinforced concrete changes the simplified suppositions of designing and should be accurately taken into account in the analyses. On the other hand, the necessity of pops in these walls is often inevitable in the non-linear behavior due to architectural or constructive reasons.(hitaka,2003). The shape and place of the holes of shear walls are effective on tensions and the elastic and non-elastic transformation and also the formability, bending resistance and capacity of absorbing energy at times of 
earthquakes. Thus, it is necessary to pay attention to the non-linear behavior of steel shear walls with pops and consider some strategies for reinforcing the sides of the pops. Also regarding the lack of enough experimental studies on the behavior of steel shear walls with pops under the effect of cyclic loading due to economic and time reasons and lack of an appropriate analysis method for determining the capacity of steel shear walls with pops, performing numeric studies in this regard is of significant importance.

\section{A BRIEF REVIEW OF THE LITERATURE}

Sabouri-ghomi gholhaki (2008) studied the non-linear behavior of steel shear walls with pops with incoming and outgoing loading and semi-static way on 16 thin non-reinforced panels in small scale for examining the load-displacement features. These samples include steel foils that are attached to a fourhinge frame by a screw. Some panels have holes. Incoming and outgoing loading was done in the direction of diameter for making a pure cut. All panels showed enough formability and they concluded that resistance and hardness reduce in a linear way against $(1-\mathrm{D} / \mathrm{d}) . \mathrm{d}$ is the height of panel and $\mathrm{D}$ is the diameter of pop. In these studies, also an analytic model of the hysterias behavior of cutting panels was gained. (sabouri,2008). Also Roberts (1991-1992) examined the behavior of shear panels and the effect of round pops on the resistance and hardness and results showed that the resistance and hardness of the foil and pop reduce with the ratio of (D/d, $d$ as the height of panel and $D$ as the diameter of pop) compared with the hardness and resistance of the foil without pop, and the results of these tests were used for determining the behavioral load-displacement curve of the foil with pop. (Roberts,1992). Tasnimi (2000) attended to the experimental study of reinforced concrete shear walls under the effect of cyclic loading. In this experimental study, 4 different samples of reinforced concrete shear walls with $500 * 1500 * 50$ dimensions were exposed to the effect of 4 different cyclic loadings. Finally, the diagrams of lateral forcedisplacement were drawn for the 4 samples. (tasnimi,2000). Brunio (2004) for the purpose of reducing the general resistance of the panel, examined the shear panel with a considerable number of holes compared with the sample without pop. The goal of this study was mostly examining the effect of extensive pops on the reduction of hardness and elastic resistance of the panel. They concluded that by making round extensive pops in the foil with higher thickness, one could reach the desired hardness and resistance in the design. (bruneau,2004).

\section{METHODS}

6 steel shear walls with pops and a cut surface, with the same length and extent of hardness by experimental studies done, were examined by researchers up to the point of break. From the 6 mentioned samples under the cyclic loading, 3 were related to the experimental test done by Sabouri et al and the other 3 belonged to the experimental test of Alavi et al. the study done by Sabouri et al has a pop in a rectangular way and each sample has 2 pops with same dimensions but with different distances. Pops have dimensions of $488 * 258$ and have hardeners. The features of all walls and loadings are shown in the following figures. The study done by Alavi e al has shear walls with one pop in a round shape, pops have a diameter of $400 \mathrm{~mm}$ in the middle of the wall, and the steel shear wall has diametric hardeners. The proper element dimensions for meshing of the original and reinforced models was selected as $100 * 100$. In this study, for modeling the steel shear wall the two-line full elasto-plastic model with kinematic hardener was used.

Table 1. The features of the used steels

\begin{tabular}{|c|c|c|c|c|}
\hline \multirow[t]{2}{*}{ Thickness of steel foil } & \multicolumn{4}{|c|}{ Features of armatures } \\
\hline & $\begin{array}{r}\text { Surrender } \\
\text { resistance } \\
\text { (Mpa) }\end{array}$ & $\begin{array}{r}\text { Final resistance } \\
(\mathrm{Mpa})\end{array}$ & $\begin{array}{r}\text { Elasticity } \\
\text { module } \\
(\mathrm{Mpa})\end{array}$ & $\begin{array}{l}\text { Percentage } \\
\text { of final } \\
\text { strain }\end{array}$ \\
\hline \multicolumn{5}{|c|}{ Saeid Sabouri-Ghomi, Salaheddin Mamazizi } \\
\hline $2 \mathrm{~mm}$ & 189.5 & 299.9 & $206 \mathrm{e} 3$ & 46.2 \\
\hline $15 \mathrm{~mm}$ & 348.2 & 521.4 & $208 \mathrm{e} 3$ & 26.9 \\
\hline
\end{tabular}

Submit Date: 11.06.2016, Acceptance Date: 25.07.2016, DOI NO: 10.7456/1060AGSE/058 Copyright (C) The Turkish Online Journal of Design, Art and Communication 


\begin{tabular}{|c|c|c|c|c|}
\hline $20 \mathrm{~mm}$ & 415.7 & 557.2 & $209 \mathrm{e} 3$ & 25.2 \\
\hline A36 steel & 245.2 & 384.7 & $208 \mathrm{e} 3$ & 31.2 \\
\hline & & \multicolumn{3}{|c|}{ Erfan Alavi , Fariborz Nateghi } \\
\hline HEB160 (SPSW(s1,s4) & 340 & 450 & $206 \mathrm{e} 3$ & 14.4 \\
\hline HEB160 (SPSW2) & 400 & 450 & $207 \mathrm{e} 3$ & 13.2 \\
\hline Plate $($ THK. $=5 \mathrm{~mm})$ & 340 & 470 & $205 \mathrm{e} 3$ & 20.5 \\
\hline Plate $(\mathrm{THK} .=4 \mathrm{~mm})$ & 460 & 550 & $205 \mathrm{e} 3$ & 19.1 \\
\hline Plate $(\mathrm{THK} .=0.8 \& 1 \mathrm{~mm})$ & 280 & 500 & $204 \mathrm{e} 3$ & 21.6 \\
\hline
\end{tabular}

\section{EXPLANATION OF THE MODEL}

The results of numeric analysis of the final load of the steel shear wall are shown in table 2. Also the results of numeric analysis and experimental study of the final load of steel shear walls is shown in table 3. The comparison of results shows that the final load gained from numeric analysis shows a very good adaptation with the corresponding loads gained from the experiment.

Table 2. Final load of the steel shear wall gained by numeric analysis and experimental study

\begin{tabular}{|c|c|c|c|c|}
\hline & \multicolumn{4}{|c|}{$\mathrm{P}_{\mathrm{u}}$} \\
\hline \multirow[t]{2}{*}{ Steel shear wall } & \multicolumn{2}{|c|}{ Numeric analysis } & \multicolumn{2}{|c|}{ Experimental study } \\
\hline & Push & pull & Push & pull \\
\hline SSW201 & $604 / 3$ & 605 & 580 & $585 / 7$ \\
\hline SSW202 & 600 & 601 & 579 & $583 / 8$ \\
\hline SSW203 & $609 / 1$ & 610 & 582 & $587 / 3$ \\
\hline average & $604 / 46$ & $605 / 3$ & $580 / 3$ & $585 / 6$ \\
\hline
\end{tabular}

Table 3. Comparison of the final load and final displacement gained by the numeric analysis and experimental study

\begin{tabular}{|c|c|c|}
\hline \multirow[b]{2}{*}{ Steel shear wall } & \multicolumn{2}{|c|}{$\mathrm{P}_{\mathrm{u}}$} \\
\hline & $\frac{\mathrm{P}_{\mathrm{u}_{\mathrm{N}}}}{\mathrm{P}_{\mathrm{u}_{\mathrm{E}}}}$ push & $\frac{\mathrm{P}_{\mathrm{u}_{\mathrm{N}}}}{\mathrm{P}_{\mathrm{u}_{\mathrm{E}}}}$ pull \\
\hline SSW201 & $1 / 04$ & $1 / 032$ \\
\hline SSW202 & $1 / 036$ & $1 / 029$ \\
\hline SSW203 & $1 / 046$ & $1 / 038$ \\
\hline average & $1 / 04$ & $1 / 033$ \\
\hline
\end{tabular}

Table 4. Final load of the steel shear wall with rectangular pop gained by numeric analysis 


\begin{tabular}{|r|r|r|r}
\hline sample & Type of pop & Dimensions of pop & $\begin{array}{r}\text { Fu } \\
\text { Push }\end{array}$ \\
\hline SPSW2 & & & $728 / 104$ \\
\hline SQUARE200X200 & rectangular & $200 \times 200$ & $720 / 379$ \\
\hline SQUARE300X300 & rectangular & $300 \times 300$ & $707 / 47$ \\
\hline SQUARE400X400 & rectangular & $400 \times 400$ & $689 / 403$ \\
\hline SQUARE500X500 & rectangular & $500 \times 500$ & $673 / 4$ \\
\hline
\end{tabular}

As seen in the above table, with increase of the dimensions of the pop, the maximum lateral force of the wall will also increase.

Table 5. final load of the steel shear wall with rectangular pop gained by numeric analysis

\begin{tabular}{|r|r|r|r|r}
\hline Sample & Type of pop & dimensions $\begin{array}{r}\text { of } \\
\text { pop }\end{array}$ & $\begin{array}{r}\text { Distance } \\
\text { of } \\
\text { pop }\end{array}$ & $\begin{array}{r}\text { Fu } \\
\text { Push }\end{array}$ \\
\hline SPSW2 & & & & $728 / 104$ \\
\hline $\begin{array}{r}\text { SQUARE200X200-2- } \\
\text { DIS100 }\end{array}$ & rectangular & $200 \times 200$ & 100 & $701 / 246$ \\
\hline $\begin{array}{r}\text { SQUARE200X200-2- } \\
\text { DIS200 }\end{array}$ & rectangular & $200 \times 200$ & 200 & $704 / 322$ \\
\hline $\begin{array}{r}\text { SQUARE300X300-2- } \\
\text { DIS200 }\end{array}$ & rectangular & $300 \times 300$ & 200 & $675 / 12$ \\
\hline $\begin{array}{r}\text { SQUARE400X400-2- } \\
\text { DIS200 }\end{array}$ & rectangular & $400 \times 400$ & 200 & $640 / 838$ \\
\hline $\begin{array}{r}\text { SQUARE500X500-2- } \\
\text { DIS200 }\end{array}$ & rectangular & $500 \times 500$ & 200 & $603 / 367$ \\
\hline
\end{tabular}

As seen in the above table, with the increase of the number and dimensions of the pop, the maximum lateral force of the wall will also increase.

\section{CONCLUSION}

The limited element analysis of steel shear walls with pops and hardener by Abaqus software was presented and the round and rectangular pop models were examined. The dimensions, selected backrests and the features of the shear wall models were the same with the features of the related shear walls of the two experimental studies. As it is seen, by increase of the dimensions of the rectangular pop in a same displacement, the maximum lateral force of the wall reduces. By increase of the number of pops and the distance of pops from each other in the same displacement, the maximum lateral force of the wall reduces. By increase of the number of round and triangle pops in a same displacement, the maximum lateral force of the wall reduces. By comparison of the results of numeric analysis with the experimental results, we can indicate the following important results:

-the final load and displacement gained from numeric analysis for the steel shear walls with rectangular pops show a very good adaptation with the experimental results.

-the final load and displacement gained from the numeric analysis for steel shear walls with round pops show a very good adaptation with experimental results.

-the comparison of load-displacement curves gained from numeric analysis for all shear walls shows a very good adaptation with experimental results. 
-The numeric results show that the increase of the resistance of bars and pillars considerably increase the resistance of the shear wall.

-The final lateral load in steel shear walls with two pops in different distances were almost the same.

-the results gained from numeric analysis in most cases indicate that this method is conservative. Thus, it can be used with assurance in designing applications.

\section{REFERENCES}

Caccese, V., Elgaaly, M.,Chen, R., "Experimental study of thin steel-plate shear walls under cyclic load", J Struct Eng ASCE, 1993, 119, 573-587.

Driver, R.G., Kulak, G.L., Elwi, A.E., Kennedy, D.J.L., "Cyclic tests offour-story steel plate shear wall”, J Struct Eng ASCE, 1998, 124, 112-120.

Astaneh-Asl, A., "Seismic behaviour and design of steel shear walls", Steel TIPS Report Moraga, CA:StructuralSteelEducationalCouncil, 2001.

Alinia, M.M., Dastfan, M., "Behaviour of thin steel plate shear walls regarding frame members", J Constr Steel Res, 2006, 62, 730-738.

Omori, S.,Toyama, K., Cho, T., Takahashi, T., "Test on RC shear wall withs lits", Summaries of Technical Papers of Annual Meeting, Kanato, Japan, 1966, 204-215

Mutoh, K., Miyashita, O., Osada, M., Kanayama, H., "Stress and deformation of slit wall using FEM" Summaries of Technical Papers of Annual Meeting, 1968, 543-544.

Hitaka, T., Matsui, C.h., "Experimental study on steel shear wall withs lits", J Struct Eng ASCE, 2003, 129, 586-595.

Sabouri-Ghomi, S., Gholhaki, M. "Nonlinear behavior of strengthening steel plate shear walls with opening, Asian Journal of Civil Panels", Thin-Walled Structures, 2008, 14, 145-162.

T.M. Roberts, S. Sabouri-Ghomi. "Hysteretic characteristics of unstiffened perforated steel plate shear panels". Journal of Thin-Walled Structures, 1992, 121-127.

A.A.Tasnimi. " Strengthand deformation of mid-riseshear walls under load reversal". Engineering Structures, 2000, 22, 311-322.

M. Bruneau, D. Vian. "Testing of special LYS Earthquake Engineering, 2004, 978.

K. Behfarnia, A.R. Sayah. " FRP STRENGTHENING OF SHEAR WALLS WITH OPENINGS". ASIAN JOURNAL OF CIVIL ENGINEERING, 2012, 691-704.

13-H. Elshafie, A. Hamid, E. Nasr. " Strength and Stiffness of Masonry Shear Walls with Openings". TMS Journal, 2012, 49. 